\title{
Yet another tale of two cities: Buenos Aires and Chicago
}

\author{
Filipe Campante ${ }^{1} \cdot$ Edward L. Glaeser $^{1}$
}

Received: 25 July 2017 / Revised: 15 September 2017/ Accepted: 24 October 2017

(C) The Author(s) 2017. This article is an open access publication

\begin{abstract}
Buenos Aires and Chicago grew during the nineteenth century for remarkably similar reasons. Both cities were conduits for moving meat and grain from fertile hinterlands to eastern markets. However, despite their initial similarities, Chicago was vastly more prosperous for most of the twentieth century. Can the differences between the cities after 1930 be explained by differences in the cities before that date? We highlight four major differences between Buenos Aires and Chicago in 1914. Chicago was slightly richer, and significantly better educated. Chicago was more industrially developed, with about 2.25 times more capital per worker. Finally, Chicago's political situation was far more stable and it was not a political capital. Human capital seems to explain the lion's share of the divergent path of the two cities and their countries, both because of its direct effect and because of the connection between education and political instability.
\end{abstract}

Keywords Argentine exceptionalism · Comparative development · Industrial development $\cdot$ Education $\cdot$ Political instability

JEL Classification $\mathrm{N} 10 \cdot \mathrm{I} 25 \cdot \mathrm{L} 15 \cdot \mathrm{D} 74$

\footnotetext{
Both authors thank the John S. and Cynthia Reed foundation for financial support. Conversations with John Reed helped start this project. We also thank the Taubman Center for State and Local Government for financial assistance. We are grateful to Kristina Tobio for her usual superb research assistance and to Esteban Aranda for his outstanding assistance with the Argentine data.
}

Edward L. Glaeser

eglaeser@harvard.edu

1 Harvard University and NBER, Cambridge, USA 


\section{Introduction}

Both Buenos Aires and Chicago grew enormously over the late nineteenth century as nodes of a transportation network that brought the produce of the New World's rich, but relatively unpopulated, hinterlands to the tables of the world. (Figure 1 shows the parallel population growth of both places.) In the early 1900s, the two cities dominated meat-packing in the Americas and were great centers of grain shipments. About one-half of the populations of both cities were immigrants, who had come to take advantage of high wages in these urban areas. Both cities were governed by functioning but imperfect democracies, and both were famous for their corruption.

Over the course of the twentieth century, the paths of the two cities have, of course, significantly diverged, just as the paths of Argentina and the U.S. have diverged. Buenos Aires has had faster population growth, but Chicago has become much richer and has also been generally free of the regime-changing political uprisings that have challenged the Argentine capital. ${ }^{1}$ In this paper, we ask whether differences between the cities at the start of the twentieth century can help us to make sense of their divergent paths since then.

On a functional level, the cities in 1900s appear quite similar. In both cases, rail lines brought wheat and beef into the port. From there, the beef was processed and the produce shipped east. The stockyards that carve up cattle and pigs are big employers in both places. Refrigeration significantly aids the exports of both cities. By 1910, the income gap between the two cities had closed to the point where real wages were about $70 \%$ higher in Chicago, which is substantially less than the gap was in 1890 or today.

Yet there were significant differences in Chicago and Buenos Aires even in 1910, beyond that income gap. First, the education levels of Chicago residents seem to have been much higher. This difference does not reflect educational enrollments, which seem broadly similar after 1884 Argentine education reform. Instead, the adults coming into Buenos Aires seem to have been much less educated than those coming into Chicago. The main reason for this difference is that rural-urban migrants in the U.S. were much better educated, reflecting the strength of the American common school movement in the early nineteenth century. Chicago also had more German immigrants, who were relatively well educated, while Buenos Aires disproportionately attracted immigrants from the less well-educated countries of Spain and Italy.

Second, Chicago moved much more quickly towards being an industrial producer as well as a transformer of raw commodities. Capital per worker appears to have been about 2.44 times higher in Chicago than in Buenos Aires in 1914. Value added per worker appears to have been 2.25 times higher in Chicago, which can readily explain the $70 \%$ wage gap. Chicago's production of goods was, to a large extent, oriented towards providing goods for the prosperous Midwestern hinterland. The

\footnotetext{
1 The events at the 1968 Democratic Convention were as close as Chicago ever came to toppling a government. While many observers link the Chicago riots with Richard Nixon's success in the election, it remains true that Nixon came to power through an electoral process that is quite different from the paths to power of several 20th century Argentine leaders.
} 


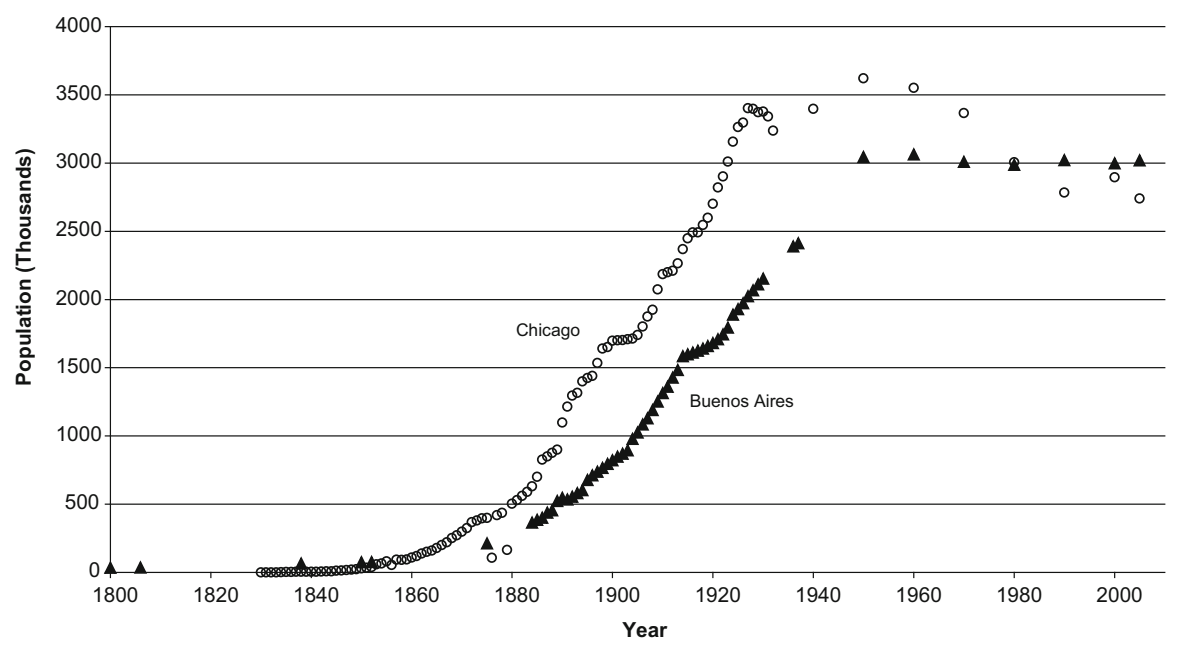

Fig. 1 Population growth of Chicago and Buenos Aires, 1800-2005. Sources: Historical data for Chicago from One Hundred Years of Land Values in Chicago, by Homer Hoyt, and data for 1940-2005 from the U.S. Census. Historical data for Buenos Aires is from Anuario Estadístico de la Ciudad de Buenos Aires and Anuario Municipal, and data for 1950-2005 from Poblacion de Buenos Aires

market for Buenos Aires-made manufactured goods was much smaller, because the Argentine farmers were much poorer. Moreover, Chicago had a long track record of innovation, and in many areas, such as mechanical reapers, it was on the forefront of new technologies. By contrast, Argentina was an importer of technological ideas through much of the twentieth century. Chicago's higher human capital levels may help explain why Chicago was more technologically developed, but in any event, by 1930, Chicago is essentially an industrial town, while Buenos Aires is still focused on raw food production and commerce.

Last but not least, political forces in Buenos Aires and Chicago were different. While Chicago had universal manhood suffrage since the Civil War, Buenos Aires had a much more limited electoral base until 1914. More importantly, Buenos Aires is Argentina's capital while Chicago is not the capital of the U.S. The combination of commerce and politics in Buenos Aires means that uprisings in the city have the ability to topple national governments. Comparable uprisings in Chicago, such as the Haymarket riot, were only of local concern. The concentration of population in Buenos Aires seems to have made the country less politically stable.

In the fourth section of this paper, we attempt to assess the relative importance of these difference factors by using cross-national evidence. Inevitably; this pulls us away from a city-level focus to a more national perspective. We examine the ability of pre-World War I variables, including income, industrialization, education, urbanization and political instability to explain cross-section income variation today. All of these variables are strongly correlated with current per capita GDP levels, but measures of schooling in 1900 have the strongest connection to modern income. Using coefficients from cross-national regressions, we estimate that the 
differences in education between Argentina and the U.S. in 1900 can, in a mechanical decomposition, explain almost all of the differences in current income levels.

But why is the connection between historical education levels and current income so tight? The direct effect of education on earnings can explain only a small portion of the link. Education, however, is also correlated with political outcomes. Stable democracies are much rarer in less well-educated countries (Glaeser et al. 2007). Lower levels of education in Argentina can help us to understand that nation's twentieth century political problems. However, education also seems to have a strong direct impact on national income levels, which can, perhaps be understood as stemming from the connection between area-level human capital and the state of technological development.

\section{Chicago del Plata; Buenos Aires on Lake Michigan}

We begin by stressing the profound similarities between the economic models of Chicago and Buenos Aires in the nineteenth century. As late as $1880,72 \%$ of the U.S. population was rural. The great wealth of the country came from its vast expanses of fertile land. No area was more fertile than the hinterland of Chicago: Illinois and Iowa. The rich black soil of America's Corn Belt yielded an average of 39 bushels per acre in 1880 , about $50 \%$ more than the older corn producing areas of Kentucky. That higher productivity explains why Chicago passed Cincinnati as America's pig-producing polis.

America's vast hinterland was enormously rich, but at the start of the nineteenth century that land was virtually inaccessible. It cost as much to ship goods 32 miles over land as it did to ship them across the ocean. Over the course of the nineteenth century, Americans built a transportation network that managed to move agricultural produce far more cheaply over space. Cities, like Chicago and Cincinnati, were nodes on that transportation network. Typically, large cities formed in places where goods needed to move from one form of transport to another.

The growth of Chicago depended on two canals. The first canal, the Erie, connected the great lakes to the Hudson River, and through it the city of Chicago was able to ship by water all the way to New York and the outside world. The second canal was the Illinois and Michigan canal, which connected the Chicago River to the Mississippi River system. Chicago's first boom decades, the 1830s, coincided with speculation related to the completion of the canal. Those two canals situated Chicago as the lynchpin of a watery arc that ran from New Orleans to New York.

As it turned out, railroads became even more important in connecting Chicago to the west. Starting in 1848, the Chicago and Galena railroad connected the city westward. While initially intended to move lead, the rail connected to Iowa and became a conduit for agricultural produce, particularly pigs. Corn is an enormously calorie-intensive crop, but it is relatively expensive to ship. Hence corn was typically fed to pigs and those pigs were moved across space. To reap economies of 
scale, Chicago became a stockyard city specializing in turning live pigs into easy-tomove salted meat.

Typically, mankind has tended to be more interested in salted pig products (bacon, sausage, ham) than in salted beef products. For that reason, in the middle nineteenth century, pigs were slaughtered in Chicago before their movement east, while cows were shipped live. One great transport innovation in nineteenth century Chicago was the four-season refrigerated rail car, used by Gustavus Swift. (His engineer's brilliant insight was to put the ice on top of the meat so it dripped down.) After Swift began using refrigerated cars, Chicago increasingly shipped prepared beef, instead of cattle on the hoof, as well as prepared pigs.

The final element in Chicago's agricultural shipping empire was its increasing role as a center for grain shipments. Wheat has less value per ton than pork or beef, and as a result high shipping costs in the middle nineteenthth century meant that wheat typically traveled short distances. Rochester, New York, for example was America's flour city in its early years, specializing in milling grain on its way to New York City. As transportation costs fell, and as hard spring wheat made the cold areas north of Chicago more productive, wheat increasingly came east from the old northwest. Chicago, as the Midwest's premier transport center, became a conduit for shipping grain as well as shipping beef and pork.

Buenos Aires' evolution in the nineteenthth century is broadly similar to that of Chicago. The similarities start with the fact that what turned Buenos Aires into a major commercial hub was its exceptionally fertile hinterland, rather than an exceptionally located port (at least when compared to possible competitors such as Montevideo). The developments in terms of the accessibility of this hinterland to the main networks of international trade were once again the key in determining the patterns followed by the city's evolution. In 1850, transportation across the Atlantic was slow and expensive, dependent on sailing ships. Argentina, therefore, specialized in exporting products that were extremely durable, such as hides and tallow. In the 1840s, Buenos Aires was exporting more than 2 million hides per year and 10,000 tons of tallow (Brown 1976). Wool was also a major export. Notably, these were the same products being produced in the region around Los Angeles around the same time and for the same reason. Distant places with abundant land were best used to produce goods that could last for months during a long sea voyage.

Over the course of the nineteenthth century, Argentina moved to higher value agricultural products, first meat and then grain. In the middle years of the nineteenthth century, Argentina was further away from European markets and had a much higher ratio of land to population than the U.S. For example, in 1880, Argentina was composed of 2.7 million square kilometers and had around 2.5 million people. The U.S. had 8 million square kilometers of land and 50 million people. The vast amounts of space in Argentina made herding relatively more attractive than intensive agriculture. While Argentina actually imported breadstuffs from Chile, in the mid-1870s, it had more than 45 million sheep and more than 5 million cattle. Since cattle and sheep complement open ranges more than pigs, beef became the primary export item for Argentina. They were, of course, and still are overwhelmingly grass fed, whereas U.S. beef primarily eats corn. 
Initially, the cattle exports were hides and some salted beef (a bit more than 20 thousand tons per year during the 1850s). The market for salted beef, such as beef jerky, was never particularly robust and this limited the growth of Argentine export trade. Two big transport innovations, however, enabled Argentina to grow dramatically as a meat exporter. First, starting in the 1840s, steam replaced sail on the cross-Atlantic journeys, reducing travel times by as much as two-thirds (from over 70 days to less than 25). Second, in 1875, refrigerated ships, or frigorificos, made it possible to ship chilled beef and mutton. The impact of refrigeration was even greater on Buenos Aires than it was in Chicago, because the distances between Buenos Aires and London precluded the shipment of live cattle in large numbers before the 1880s.

With the coming of the frigorificos, Buenos Aires became a large exporter of frozen and chilled beef and mutton. During the early years of chilled transport, mutton was actually a more important export than beef, because "mutton, unlike beef, is not injured materially in quality, flavor and appearance by the freezing and thawing process," (Hanson 1938, p. 84). By 1892, Argentina was exporting more than a million sheep carcasses annually. Faster transportation was also making it easier to export vast amounts of live cattle and sheep to the United Kingdom and other European markets, and by the turn of the century, 500,000 live sheep and 100,000 live cattle were being exported annually from Argentina to the England.

The vast increase in the amount of chilled beef exported from Argentina, much of it through Buenos Aires, actually occurred during the early years of the twentieth century. Between 1900 and 1916, Argentina's exports of frozen beef increased from 26,000 tons to 411,000 tons. About a third of those frozen carcasses were coming through the port of Buenos Aires, which was growing as a center for slaughtering and refrigeration, as well as shipping.

The final step in the agricultural development of Argentina also mirrors the changes in Chicago. Just as the decline in shipping costs made it more attractive to ship wheat from the west to New York via Chicago, easier shipping costs made wheat a more attractive export for Argentina. As late as the 1870s, Argentina was exporting essentially no wheat. By 1904, the Argentines were exporting more than two million tons of it per year.

The growth of the wheat trade was accompanied by a vast transformation on the Pampas. Land that had been used as open range became used for intensive wheat cultivation. By 1910, 10 million acres in the province of Buenos Aires were being used to grow wheat. The population of Buenos Aires' hinterland rose dramatically as immigrants came to farm. In 30 years, Argentina moved from having essentially no cereal production to becoming one of the world's three largest grain exporters.

The roots of this transformation also lay in better transportation technologies. Across the Atlantic, faster and faster steam ships made it cheaper to ship grain. Starting in the $1850 \mathrm{~s}$, a rail network was created within Argentina, generally supported by the government and mostly connecting Buenos Aires to places in the hinterland. (In yet another interesting parallel, just as a New England-born shipping magnate, John Murray Forbes, built some of the first rails that connected Chicago, a New England-born shipping magnate, William Wheelwright, built some of the first rail tracks in Argentina.) Rail allowed population to disperse through the hinterland, 
and it also brought goods into Buenos Aires to be processed and shipped out; quite crucially, it made it less expensive to ship grain to the capital. While cattle and sheep could walk on their own to the port, grain always needed to be shipped. As a result, grain particularly benefited from the improvements in rail.

In sum, like Chicago, Buenos Aires initial attraction was its harbor and waterways - the River Plata was an avenue into the interior-located next to an exceptionally fertile hinterland. The rail network, which centered at the capital, only increased Buenos Aires' place at the hub of Argentina's internal transport network, just as rail only increased Chicago's importance in the Midwest. The comparison did not escape contemporary observers, such as U.S. Trade Commissioner Herman G. Brock, who noted that "like Chicago, [Buenos Aires] has all the resources of the broad pampas at its doors and is the terminus of a dozen railways whose network of transportation covers the Republic from north to south and east to west, all feeding directly or indirectly into the capital" (Brock 1919, p. 13).

By 1910 both Chicago and Buenos Aires were "nature's metropolises." Both cities had grown great as conduits that moved the wealth of American hinterlands to more densely populated markets. In both cases, beef and wheat played a disproportionate role in the commerce of the cities. In both cases, improved shipping technologies, especially refrigeration, enabled the cities to grow.

Yet the twentieth century time paths of these places were quite different. By population, Buenos Aires grew faster, but by most other measures of progress Chicago dramatically passed its southern rival, just as the income gap between the U.S. and Argentina widened. Is it possible to see, in the differences between the two cities a century ago, the roots of their twentieth century divergence?

\section{Four differences between Buenos Aires and Chicago in 1910}

In this section, we discuss four major areas in which Buenos Aires and Chicago differed a century ago. In the next section, we connect these differences to the history of the cities and their countries since then.

\subsection{Incomes}

Income levels are the natural starting point for understanding what was similar and different between the U.S. and Argentina, so we first look at wage data for the two countries (plus Great Britain and Italy) from 1870 to 1970 (data from Williamson 1995b) in Fig. 2a-c. (The wages are normalized so that the British wage in 1905 equals 100.) At the start of the time period, wages in the United States are more than $50 \%$ higher than wages either in Great Britain or Argentina. Wages in those places are about the same and about double the wages in Italy.

Between 1870 and the early 1890s, Argentina experienced a remarkable 66\% increase in real wages. Argentina's spectacular real wage increase was accompanied by, and probably created by, the aforementioned improvements in shipping technology that enabled Argentine mutton and beef to efficiently be shipped to European markets. Argentine land was made much more productive by the ability to 

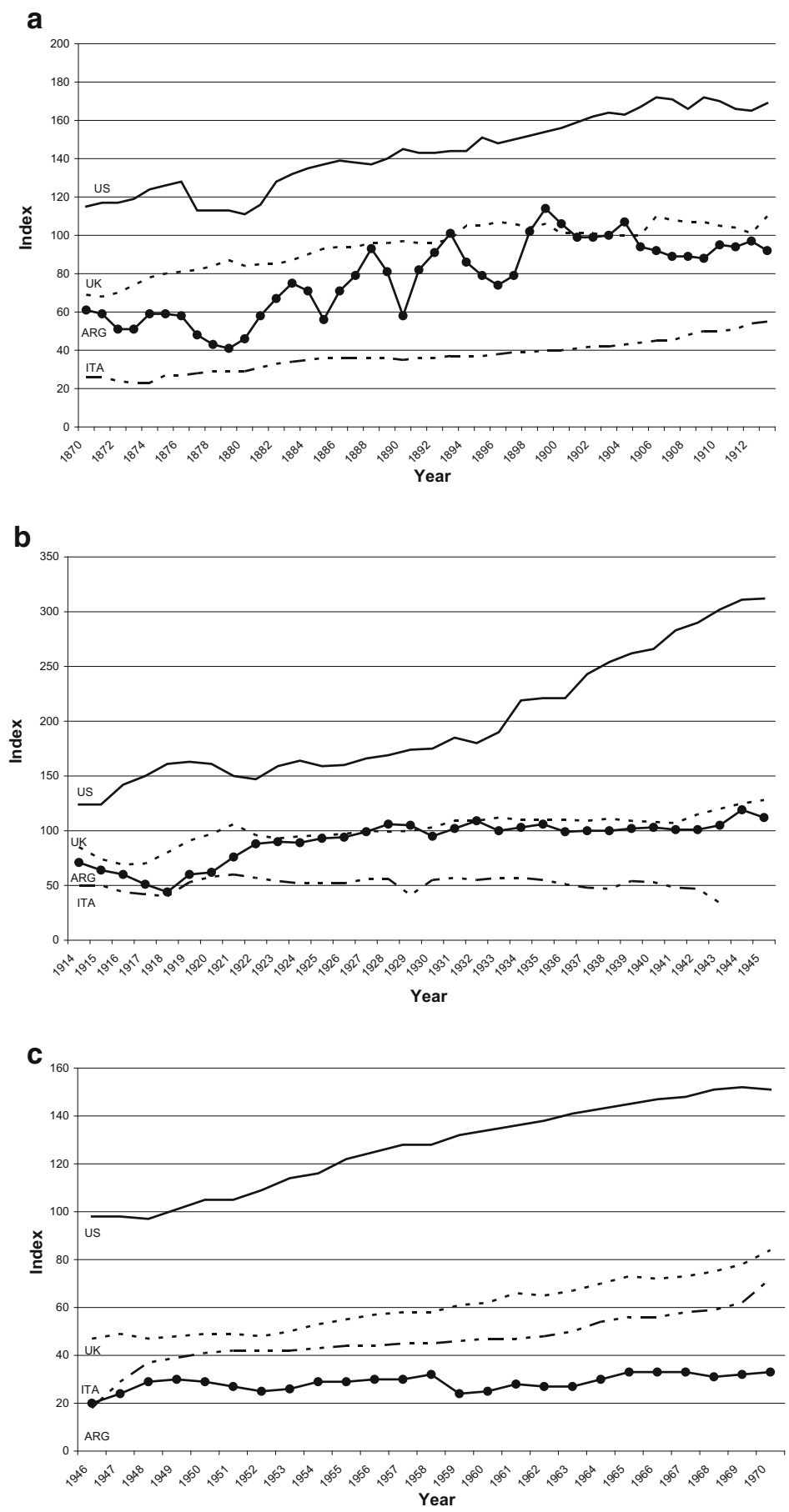
Fig. 2 a Annual Wage Data 1870-1913 (100=UK Real Wage in 1905). b Annual Wage Data 1914-1945 (100 = UK Real Wage in 1927). c Annual Wage Data 1946-1970 (100 = UK Real Wage in 1975). Source: Jeffrey G. Williamson, "The Evolution of Global Labor Markets since 1830: Background Evidence and Hypotheses"

ship meat quickly and that seems to have greatly increased the marginal productivity of labor.

Argentina was not alone in experiencing real wage increases during the late nineteenth century. American wages increased by amount the same proportion, so that in 1892 (a high water mark for Argentine wages), American wages remained 60\% above those in Argentina. Wages in Argentina and Britain remained quite similar and about double the wages in Italy, which sent many immigrants to the U.S. and Argentina during this period. Spain, another exporter of people to Argentina, also had wages that were about one-half of those in Argentina.

Of course, these aggregate wage series do not particularly tell us about similar workers in the two cities. To make the scales somewhat more comparable, Fig. 3 shows monthly wages in Chicago from the U.S. Census in 1939 dollars. In Chicago, these wages rose substantially over the 1880 s and then remained remarkably static in real terms from 1890 to 1920. Over this time period, of course, the size of Chicago's large force was increasing dramatically. The city expanded from 500,000 to 2.7 million. That vast influx of labor surely played a major role in keeping wage growth modest. The slower population growth over the 1920s, when America substantially reduced the flow of foreign immigrants, may explain rising real wages during that decade.

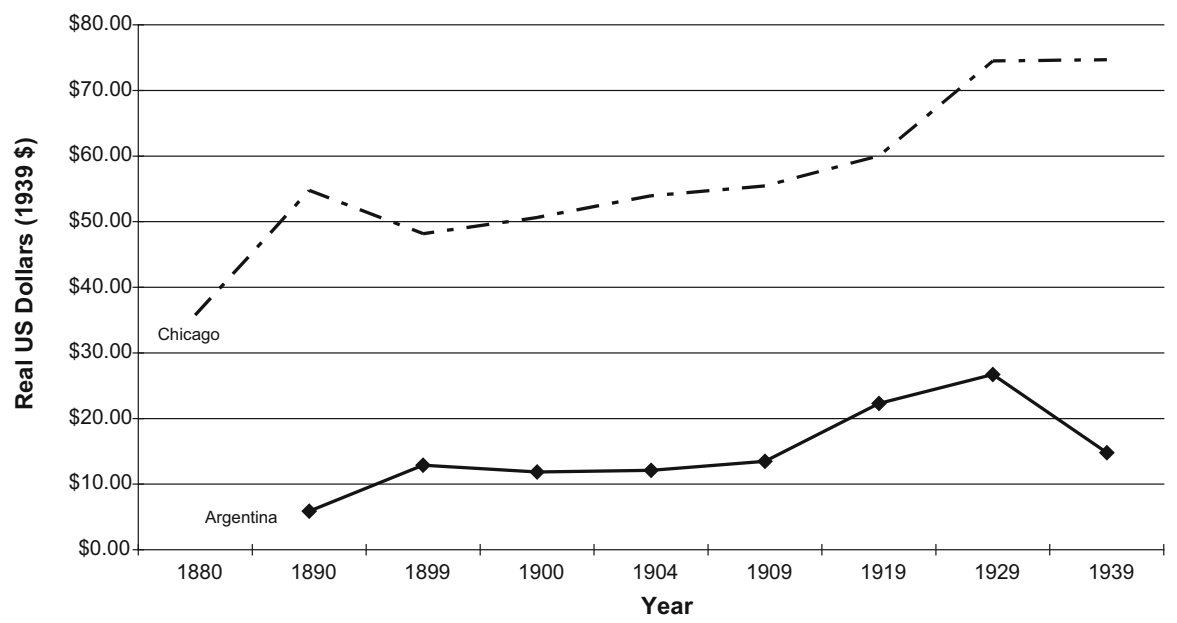

Fig. 3 Real monthly wages in Chicago and Argentina, 1880-1940. Sources: Chicago data from the U.S. Census. Argentina data from Williamson (1995a) and DiTella and Zymelman (1967) 
We do not have data on wages in Buenos Aires itself. Instead, we are forced to use national industrial data. However, much of Argentina's industry was in the capital, so this should give us some sense about wage levels for manufacturing workers in Buenos Aires. While there are many ups and downs, over the whole period, Argentine industrial workers become steadily better paid, as shown in the Williamson data. Throughout the entire period, however, the workers in Chicago were earning more in real terms than the workers in Buenos Aires. During most of the time, the wage gap was approximately $70 \%$. At the start of the century, before the great divergence, there was already a very substantial income gap between the two cities.

Why were the workers in Chicago, many of whom were doing comparable things, earning much more? Classical economics pushes us to consider wages as the intersection of labor supply and labor demand. Labor demand, in turn, reflects the marginal productivity of labor. The higher wages in Chicago, therefore, imply that labor was more productive in that city. Why?

There are three primary hypotheses. First, the workers in Chicago had more skills than the workers in Buenos Aires. We will treat this hypothesis in the next section, where we document significantly greater education levels in Chicago. This gap surely explains some of the difference. However, evidence on wages and schooling from within the U.S. makes it clear that education differences alone cannot explain the gap.

A second hypothesis is that Buenos Aires and Chicago had different amounts of capital, and greater capital levels in Chicago increased the productivity of workers in that city. We will turn to that hypothesis later, when we address the industrial mixes of the two cities. Chicago appears to have had about 2.44 times more capital worker, which in a standard Cobb-Douglas production function might suggest that wages would be $30 \%$ higher in Chicago. This can explain almost one-half of the gap.

Finally, a third hypothesis is that Chicago firms were more productive, either because of more advanced technologies or because of the greater distances between Buenos Aires and European markets meant that Argentine products were worth less, at their point of production. The American workers were often much closer to their customers and this decreased one cost of reduction and thereby increased the marginal productivity of labor.

The labor supply curve also gives us information about the reasons for and the nature of wage disparity between Chicago and Buenos Aires. Both cities attracted very significant amounts of immigration between 1890 and 1910. The 1910 census shows that $36 \%$ of Chicago's white residents were foreign born, out of which $16 \%$ were from Russia, 23\% were from Germany, 17\% were from Austria and 6\% were Italian. In Buenos Aires, the estimates from the Buenos Aires Statistical Annual (Anuario Estadistico de la Ciudad de Buenos Aires 1925) indicate that the city's population increased by $140 \%$ over those two decades, and more than half of that increase was due to immigration. As a result of this massive inflow, $50 \%$ of Buenos Aires' residents were foreign born in 1914. Buenos Aires' immigrant population was by then overwhelmingly Spanish and Italian, as can be gleaned from the national data: in 1914, roughly $10 \%$ of the Argentine population was born in Spain, 
and $12 \%$ in Italy; natives of the two countries made up roughly three-fourths of the total foreign-born population of the country.

The fact that Italian immigrants were going in large numbers to both Buenos Aires and Chicago is puzzling if the real wage differences are actually of the order of $70 \%$. Why would an Italian immigrant choose Buenos Aires over America knowing that real wages are likely to be so much less? There are three possible explanations for this phenomenon. First, it is possible that Buenos Aires offered amenities, like a better climate and a different culture, that were missing in Chicago. Second, the immigrants going to Chicago and Buenos Aires might have actually been quite different. Third, the real wage differences might have been smaller than they appear.

The first hypothesis surely has some truth to it. The fact that Spaniards were drawn to Buenos Aires, despite lower real wages, would not seem like that much of a puzzle. After all, Argentina is a Spanish-speaking country with a Latin culture. The attraction of Buenos Aires is understandable. Italians were also attracted to Buenos Aires because of the similarity in languages (and culture) between Italy and Spain.

There were also substantial differences in the populations going to the U.S. and Argentina. For example, between 1884 and 1886, two-thirds of the Italian immigrants coming to Argentina were from Northern Italy. During the same years, $85 \%$ of Italian immigrants coming to the U.S. were from the south. During later periods, the differences narrowed: in the 1907-1909 period; the number of southern Italian immigrants to Buenos Aires had soared, and $31 \%$ of the Italian immigrants came from the north. Still, that number was much higher than in the U.S. where only 9\% of Italian immigrants came from Northern Italy.

The somewhat different regional origins suggests that, at least during the earlier periods, the U.S. had greater attraction for the southerners while Argentina had greater attraction for the northerners. The Northerners were generally much more skilled: only about $12 \%$ of the northerners were illiterate, while $54 \%$ of the southerners were illiterate. One interpretation is that the Southerners went to America, where industrial wages were higher. The northerners, however, saw greater returns to going to Buenos Aires, which was notably lacking in more skilled workers. (As we will see in the next section, Buenos Aires was, throughout most of the period, a significantly less well educated city than Chicago.) This suggests that the overall pattern of higher wages in Chicago might mask heterogeneity in the wage differentials for different skill profiles.

Finally, the pull that Buenos Aires had to many immigrants does suggest that real wages might not have been quite as low as they seem relative to the U.S. The economic question is how much of a real wage discount would immigrants have been willing to accept to live in Buenos Aires rather than in the U.S. This remains an open question.

In any event, the weight of evidence suggests that, one century ago, Chicago already had higher income levels than Buenos Aires. The next two subsections will dig deeper into the possible reasons behind that disparity. 


\subsection{Education}

While wages were certainly lower in Buenos Aires than in Chicago, wagescorrecting for education-differ less. The Argentines appear to have been significantly less educated for much of this time period. Unfortunately, literacy remains the primary means of measuring education levels, and that, of course, is a quite coarse measure. Nonetheless, Fig. 4 shows literacy rates for Buenos Aires and Chicago during our period.

In Chicago, overall literacy rates for the population aged ten or older start above $95 \%$ in 1870 and stay at that level for the next 60 years. There is a gap between native and foreign born, but even among foreign born Chicago residents' literacy is never less than $87 \%$. Native literacy is always over $98 \%$, suggesting that pretty much everyone in the city knew how to both read and write.

By contrast, the Buenos Aires data suggest that less than one-half of the population could both read and write in 1869. By 1895, the next available data point, the literacy rate had shot up to $72 \%$, which still meant that a substantial portion of the population was unable to either read or write. It is not until 1939 that more than $90 \%$ of the population in Buenos Aires is literate. The data are not entirely comparable since they refer to different age groups; still the differences are quite striking.

Why is there such a difference in literacy rates between the two cities? Table 1 shows school enrollment rates over time for Chicago and Buenos Aires. While enrollment rates are somewhat higher in the U.S., the rates seem much closer than the literacy rates would suggest. The political leaders who came to power after Rosas, such as Mitre and especially Sarmiento in the 1860s and 1870s, were quite

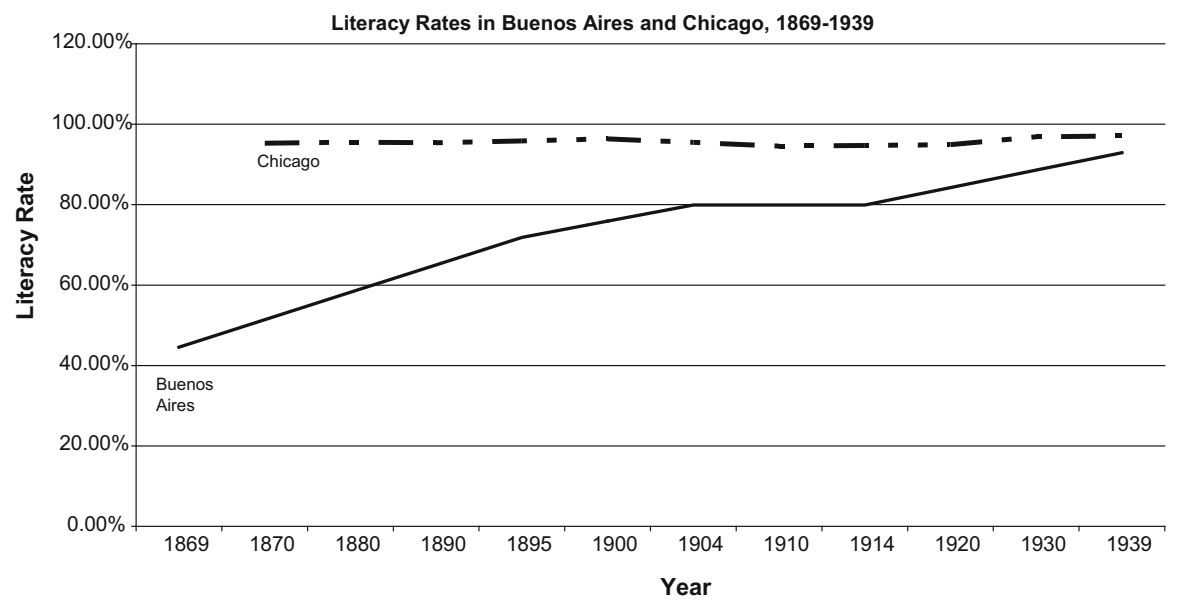

Fig. 4 Literacy rates in Buenos Aires and Chicago, 1869-1939 Sources: Data for Chicago from the U.S. Census IPUMS (Integrated Public Use Microdata Series) at http://www.ipums.org. Data for Buenos Aires from Primer Censo Nacional (1869), Segundo Censo Nacional (1895), Censo General de la Ciudad de Buenos Aires (1904), Tercer Censo Nacional (1914) Tomo III, and Cuarto Censo General de la Ciudad de Buenos Aires (1939) 
Table 1 School enrollment in Chicago and Buenos Allies

\begin{tabular}{|c|c|c|c|c|c|c|}
\hline \multicolumn{3}{|c|}{ Chicago } & \multicolumn{4}{|c|}{ Buenos Aires } \\
\hline \multicolumn{3}{|c|}{ Children aged $15-14$} & \multicolumn{4}{|c|}{ Various age groups } \\
\hline Year & $\%$ in school & $\begin{array}{l}\text { Total population } \\
\text { (of age group) }\end{array}$ & Year & $\%$ in School & $\begin{array}{l}\text { Total population } \\
\text { (of age group) }\end{array}$ & \\
\hline 1870 & 66.14 & 61.874 & 1883 & 64.63 & 52.231 & Age $5-14$ \\
\hline 1880 & 54.96 & 106.543 & 1895 & 57.72 & 117.388 & Age 6-14 \\
\hline 1890 & 66.39 & 214.470 & 1904 & 67.45 & 188.271 & Age $6-15$ \\
\hline 1900 & 64.82 & 342.000 & 1943 & 90.10 & 290.922 & Age $6-13$ \\
\hline 1910 & 85.52 & 353.520 & & & & \\
\hline 1920 & 89.80 & 486.969 & & & & \\
\hline 1930 & 86.34 & 553.884 & & & & \\
\hline
\end{tabular}

Sources: (1) All of the Chicago data are from are from IPUMS. except 1890 which is from die print edition of the 1890 census. (2) Censo Escolar Nacional -correspondiente a fines de 1883 y principios de 1884. Segundo Censo Nacional (1895). Censo General de la Ciudad de Buenos Aires (1904). Tercer Censo Nacional (1914). and Cuarto Censo Escolar de la Nación (1948)

committed to public schooling. In 1884, Argentine law made free, secular public schools a right - the Ley 1420 enacted by President Roca, and pushed by Sarmiento in his post-presidency role as head of the National Education Council. There are good reasons to believe that these schooling efforts were particularly successful in the capital, as is apparent from the enrollment data. As such, we can not explain the literacy gap with different enrollment rates alone.

One explanation for the difference is that immigrants who came to Argentina were significantly less literate than their American counterparts. Just as in the U.S., there is a gap between native and foreign born Argentines. In 1904, for example, $89 \%$ of native Argentines were literate, but only $72 \%$ of the foreign born in the city could read and write. In 1900 Chicago, by contrast, 93\% of the foreign born were literate. Chicago's more Germanic population appears to have been much more skilled than the southern Europeans who came to Argentina. Even though Argentina received a higher share of northern Italians, this did not overcome the basic pattern of attracting much less literate people.

The skill differences between Buenos Aires and Chicago do not just reflect differences in foreign immigration. They also reflect the different levels of schooling in the American hinterland. Chicago was a city of immigrants, but it was also a city full of farm boys and girls who had come to town. Likewise, a large share of Buenos Aires residents was born outside the city in Argentina. While school enrollment rates look broadly similar between Buenos Aires and Chicago, outside of the cities the differences in schooling look rather more substantial.

During the first part of the nineteenth century, American rural areas had embraced the common school movement. Farmers throughout the country had been convinced that educating their children was a worthwhile endeavor that would make them more productive. By contrast, the large ranches that predominated in the Argentine hinterland made no such investments in education. One explanation for 
the difference is that the returns to skill were much lower in Argentine ranches than in intensive agriculture. Land appears to have been much more widely owned in the U.S., and skills were presumably higher for yeomen farmers than for gauchos.

As a result, the rural areas that fed people to Chicago were reasonably well schooled. The hinterland of Argentina was not, at least prior to 1880. For example, the 1869 census shows that, even after the public education initiatives of the Mitre presidency (although still at the outset of the heavily education-minded Sarmiento presidency), only one in five Argentinean school-age children were enrolled in school. Since that includes data on Buenos Aires, we are led to conclude that the situation in the hinterland was considerably worse than that.

How much of an earnings wedge can be explained by literacy alone? Using data on wages by occupation in 1940 (the first time such data are available), we can estimate a 1940 wage for each occupation in the 1900 U.S. Census. We then estimate the average 1940 wage earned by literate and illiterate Chicagoans.

We find that the average wage earned by an illiterate was $56 \log$ points lower than the average wage earned by someone who could read and write. That premium survives controlling for individual age, and controlling for country of origin reduces the measured premium to $34 \log$ points.

While that premium is extremely significant, it is not enough to explain most, or even much, of the wage gap between Chicago and Buenos Aires at the turn of the last century. $16 \%$ more of Argentina's population was illiterate than the Chicago's population. Multiplying $16 \%$ by even a $56 \%$ wage loss leads to an estimate that Buenos Aires should have had $8 \%$ higher wages if illiteracy was the only thing holding them back. This modest number is dwarfed by the actual $70 \%$ wage gap.

Of course, illiteracy is presumably just proxying for a large educational gap between the two groups. Still the wage gap seems far too large to be explained by education alone in a simple model where human capital produces productivity. If the returns to schooling were about $7 \%$ per annum, then Chicagoans would need to have the equivalent of 10 extra years of schooling to explain the observed wage difference, which is wildly implausible.

It is, of course, possible that wages impact earnings directly and through human capital externalities. An example of such externalities might be that more education leads to more innovation and better technology for everyone. In that case, the impact of greater skills in Chicago would be larger. Still, we suspect that this effect would show up mainly in the occupational and industrial distribution of the two countries, and we turn to that next.

\subsection{Industrialization}

Both Chicago and Buenos Aires owed their growth to their roles as centers for the shipment of natural produce. Both cities also developed other industries which produced goods for people living in the hinterland and the residents of the city itself. Cyrus McCormick is the quintessential example of an industrialist who moved his mechanical reaper operation to Chicago in order to be close to his customers, the farmers of the Midwest. Buenos Aires also had its industrialists, like Ernesto Tornquist, who invested in large factories. 
While both cities certainly had industry, Chicago's industry developed earlier and was far more capital-intensive on the eve of World War I. By 1900, 15\% of Chicago's population, 262,261 workers, labored in industrial pursuit. Four years later, only $7 \%$ of Buenos Aires' population, 68,512 people, were in manufacturing. After that point, however, the share of Chicago's workers in manufacturing stagnated while the share of Buenos Aires workers in manufacturing continued to rise. As a result, their employment in industry converged. By 1914, Chicago had 313,000 industrial workers, or $13 \%$ of the city's population. Buenos Aires province had 149,000 industrial workers, which was $9.4 \%$ of the city's population.

These similar employment shares were not matched by similar levels of output. In 1914, the U.S. Census writes that the value of Chicago's industrial output is 1.48 billion dollars (or 30 billion in current dollars); the value added by manufacturing was 581 billion dollars (or about 12 billion dollars today). Each Chicago worker was associated with 4728 dollars of output (about 100,000 dollars today) or 1856 dollars of value added (about 38,000 dollars today).

In Buenos Aires, total output was 280 million dollars and value added was 122 million dollars. On a per capita basis, each Buenos Aires worker was producing 1880 dollars worth of output (or 38,000 dollars today) and 819 dollars of value added (about 17,000 dollars today). Per worker output was 2.5 times higher in Chicago than in Buenos Aires. Per worker value added appears to have been 2.25 times higher in Chicago than it was in Buenos Aires. This difference in productivity is much larger than the $70 \%$ difference in manufacturing incomes that we found during this time period.

Why was manufacturing more productive in Chicago than in Buenos Aires? One hypothesis is that the level of capital per worker was higher in Chicago. In 1914, the total capital in the manufacturing sector was 1.19 billion dollars or 3800 dollars per worker (78,000 today). In 1914, Buenos Aires had 231 million dollars worth of capital or 1550 dollars per worker (32,000 today). The Chicago workers had 2.44 times more capital per worker which may help to explain the higher levels of productivity.

Using a standard Cobb-Douglas production function, we can estimate whether these capital differences can help explain the labor productivity differences across space. This assumes that output equals $A K^{\alpha} L^{1-\alpha}$, where $A$ reflects productivity, $K$ reflects capital, $L$ reflects labor and $\alpha$ reflects capital's share in output (typically taken to be one-third). This equation then implies that per worker productivity equals $A(K / L)^{\alpha}$, which would equal A times the capital to labor ratio to the power 1/3. If the capital/labor ratio was 2.44 times higher in Chicago than in Buenos Aires, this would predict that productivity would be $34 \%$ higher in Chicago. Thus, higher capital levels alone can only explain about $27 \%$ of the higher productivity levels in Chicago. The remaining $73 \%$ of the gap in productivity must be associated with the catchall variable " $A$ ", which describes total factor productivity. To explain a $125 \%$ greater productivity per worker in Chicago, total factor productivity must be $67 \%$ higher in that city.

The productivity gap can come from three sources: human capital, transportation costs and technological development. We have already noted that human capital appears more developed in Chicago. The Cobb-Douglas model, as written above, 
assumes that labor is measured in equivalent units. Assuming that $L$ equals the number of workers times human capital per worker, implies that per capita productivity will increase by human capital to the power 2/3. If Chicago's workers had 20\% more human capital per worker (which seems high), then this would predict a $13 \%$ increase in productivity in Chicago, which can explain another $10 \%$ of the observed productivity difference.

This would leave about $60 \%$ of the productivity difference to be explained by differences in " $A$ ", the productivity parameter, reflecting either more developed technologies or easier access to consumer markets. It is difficult to determine how much of the difference in productivity can be explained by either force. Chicago's industrialists certainly found it easier to sell to a much richer and larger market in the United States. The total GDP of the U.S. was about 18 times larger than the GDP of Argentina in 1913. Argentina's hinterland was filled with large numbers of relatively poor people; the farmers of the Midwest were much wealthier.

In principle, Argentina could have exported manufactured goods to Europe, but they do not appear to have done that. Almost all of Argentina's exports in 1914 were agricultural, which surely reflects the country's comparative advantage and the large shipping costs for manufactured goods. By contrast, America was an industrial exporter in 1900, and goods from Chicago, like McCormick's reapers, were traveling the globe. Still, it seems likely that these sales tell us more about technology than about transportation costs. In principle, reapers built in Buenos Aires could have been shipped to Russia, just like those in Chicago. It is not obvious that the costs would have been that much higher, if at all. The difference was that Chicago was at the cutting edge of reaper technology, while Buenos Aires was not.

A quick look at Chicago's industrial sectors gives us a sense of the city's level of technology. Table 2 lists the top five industries, by employment, for Chicago in 1910 and Buenos Aires in 1914. A few large industries dominated Chicago manufacturing in the years before World War I. The largest sector was men's clothing production, which employed 38,000 people in 1909. Another 37,000 were in foundry and machine shop products. 27,000 worked in meat-packing. There were also 33,000 in printing and publishing. 12,000 people worked in lumber. 12,000 more workers made cars. 11,000 Chicagoans made furniture and refrigerator units. The meat-packers were directly transforming the products of Chicago's hinterland, but the others were working in more advanced products.

Clothing was also Buenos Aires largest industrial sector in 1914, with 36,000 workers. Moreover, the capital/labor ratios were pretty similar in both cities: both men's clothing in Chicago and "dressing" (vestido y tocador) in Buenos Aires had about 750 dollars per worker in capital, which suggests that both industries were labor-intensive and using relatively similar technologies. In the clothing sector, the level of horsepower per capita was actually higher in Buenos Aires than in Chicago.

The fact that the clothing manufacturers in Chicago were more productive presumably reflects more about the available market, than anything about the state of clothing production technology in the Windy City. Chicago's clothing manufacturers had particularly benefited by the distribution networks in the Midwest put together by Chicago-based retail pioneers, such as Marshall Field, John 


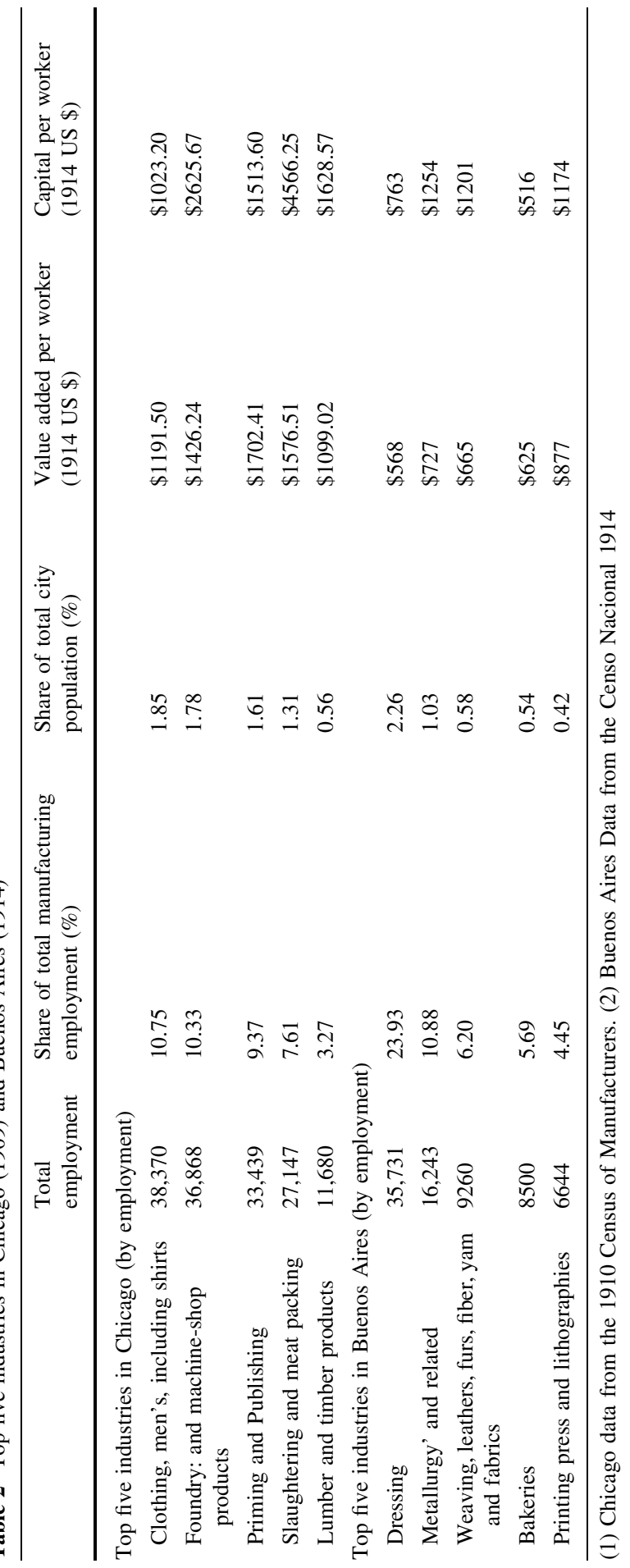


Shedd (who worked for Field), Montgomery Ward, Richard Sears and Julius Rosenwald (who led Sears, Roebuck after Sears).

However, in other areas, there is much more evidence of Chicago's technology superiority. For example, Chicago had about 12 times more employment in car production in 1910 than Buenos Aires did in 1914. Automobiles in that era were a cutting-edge technology. Argentines would purchase plenty of cars in the teens and 20s, but the bulk of them were imported, often from the United States.

Chicago had 37,000 people in foundry and machine shop products relative to 16,000 people in Buenos Aires in metallurgy. However, in this case, the Americans appear to have been far more industrially advanced using 55,000 units of horsepower (or 1.1 per worker) as opposed to 8000 (or 0.5 per worker) in Buenos Aires. The Chicago workers had 2400 dollars of capital per worker; the blacksmiths in Buenos Aires had less than half that. These different levels of capital suggest that the Argentines were following a much more primitive model of metal machine production than their Chicago counterparts.

Chicago also appears to have been at the forefront of a number of technological breakthroughs, beyond McCormick and his reaper. In the nineteenth and early twentieth centuries, Chicago innovators created the skyscraper, the electric washing machine, the zipper and a host of other significant inventions. It is difficult to find any comparable breakthroughs for Buenos Aires.

Evidence for significant differences in the state of technology also appears in many industrial histories. For example, Torcuato DiTella was a leading Argentina industrialist over the first half of the twentieth century. While DiTella's first success came with a bread-kneading machine that he invented himself, many of his later successes came from importing American technology. For example, in the 1920s, he catered to Argentina's growing population of drivers (many of whom were in American cars), by providing a new gas pump through a licensing arrangement with the American Wayne Gas Pump company. In the 1930s, he began making refrigerators, first licensing from Kelvinator and then Westinghouse.

Why was Chicago more technologically sophisticated than Buenos Aires a century ago? There were surely many reasons, but human capital seems like a particularly important explanatory variable. Education helped spread ideas in the U.S. and gave engineers the background needed for more innovation. The differences in schooling between the two countries help us to understand why America had more developed industries a century ago.

\subsection{Politics}

The final major difference between Buenos Aires and Chicago lies in the area of politics. The Argentine Constitution of 1853 has a large number of similarities to the U.S. Constitution, which is not entirely coincidental, as the Argentines looked, in part, to the U.S. model. As in the U.S., there are three branches of government, and a bi-cameral legislature. The legislature included both a directly elected house, the Chamber of Deputies, and an indirectly elected legislature, the Senate. Moreover, between 1862 and 1930, Argentina maintained a reasonable amount of political stability, maintaining at least the appearance of a stable democracy. 
Beneath this appearance, however, there were at least four major areas in which Argentina and the United States differed for at least some of that post-Rosas time period. First, until 1912, Argentinean suffrage was far more restricted than that of the United States. For example, after 1850, no U.S. state had property rights requirements for voting. By 1860, any of the old tax requirements had also disappeared. Of course, some American states did impose "literacy" qualifications, often in an attempt to exclude African-Americans from voting, but aside from African-Americans in southern states, essentially all American men could vote by the Civil War.

By contrast, universal male suffrage did not appear in Argentina until 1912. For example, as late as 1896, Banerjee et al. (2006) estimate that only $1.6 \%$ of Argentina's population voted, in part because of literacy and wealth requirements. Alonso (1993) documents that $1.8 \%$ of the city's population, or less than $4 \%$ of the male population, voted in the 1896 election. By contrast, more than $40 \%$ of Illinois' male population voted in the 1896 U.S. Presidential election, which suggests a far more open democracy in Chicago than Argentina.

In addition to the limits on suffrage, the Argentinean electoral system did not have a secret ballot. Instead, the voto cantado ("sung ballot") - in which each voter would come to the electoral precinct and loudly declare his preferred candidate, upon which the electoral authority would write it down-guaranteed that a local caudillo could pressure voters into supporting the candidate of his choosing. Ironically, the allegedly liberal arguments often advanced by urban interests against the extension of the franchise - the idea that rural oligarchs would just manipulate their workers' votes-found their match in the allegedly enlightened arguments of the landed oligarchy against the secret ballot, as they argued that it would deprive ignorant workers from the "healthy influence" of their landlords (Sampay 1974).

Argentina's voting rules evolved over the period 1890-1910 (Alonso, 1993), and the country moved to universal manhood suffrage and the secret ballot in 1912, with the passage of the Sáenz Peña law. Engerman et al. (2000) document that voter participation increased to $9 \%$ (or $18 \%$ of the male population) in the 1916 election and $12.8 \%$ (or $25 \%$ of the male population) in the 1928. By 1920, both Chicago and Buenos Aires had mass democracy, but that democracy was much younger in Argentina. As (at least some) political institutions take time to mature, the novelty of that democracy in Argentina may have added to its weakness.

Not only were electoral rules different between the two cities until 1912, electoral practices were as well. It is unclear if Buenos Aires or Chicago had more electoral corruption, as allegations of voter abuse flew in both places. Textbooks on Argentinean history regularly describe the corruption of nineteenth century politics. The voto cantado system, in particular, gave tremendous power to the electoral judges who were in charge of writing down the vote announced by each voter and invited widespread corruption on their part. For example, Rock (1987) writes that "only a small fraction of the nominally enfranchised population voted in elections, which local bosses regulated by manipulating the electoral roles or by simple bribery and intimidation."

However, American politics during the Gilded Age was hardly a model of probity. The tale of Charles Yerkes and his acquisition of traction franchises with 
payments to Chicago politicians, told in fiction by Theodore Dreiser, is among the most famous of all Gilded Age political stories. As late as 1960, rumors alleged that Mayor Daley had manufactured vast numbers of votes for John F. Kennedy in Chicago. Since electoral fraud is hard to measure, and allegations of fraud abound in both places, it would be hard to claim any clear ranking between the two cities in that area.

In any event, it is certainly true that mass violence was far more regular in Argentina than in the U.S., at least after the bloodbath of the Civil War. It is clear that elections in Chicago were not leading to major armed outbreaks. America, of course, did have one election which ended up in open warfare, but after 1865 disagreements over outcomes did not lead to large-scale battles. Not so in Argentina.

Buenos Aires was no stranger to political conflict during the late nineteenth century and early twentieth century. In 1880, 1890, 1893 and 1905, Argentina experienced major uprisings; three of those started in Buenos Aires, and the fourth also reached it. The 1880 uprising was associated with the election of Julio Roca as President of Argentina. Roca was seen as favoring nationalization over decentralization and he defeated Carlos Tejedor, a favorite in Buenos Aires. After the electoral defeat, 10,000 Buenos Aires residents rose up and a bloody battle ensued with 3000 casualties. Roca secured the presidency, and the centralization of Argentina, only by suppressing the revolt.

After that point, the República Conservadora ("Conservative Republic") that lasted between 1880 and 1916, under the oligarchic rule of the so-called Generación del'80 ("Year'80 Generation"), faced constant pressure from the "Radical" opposition. This often spilled into armed conflict, such as in 1890, 1893 and 1905. The 1890 revolution was associated with the somewhat leftist Civic Union group, which was actually led by Mitre himself, and it aimed to topple the President Miguel Celman. In that, the uprising succeeded and led to the presidency of Carlos Pellegrini, who was a general opposing the revolt. In 1893, an uprising led by the Radical Civic Union, an offshoot of the Civic Union, started in the Santa Fe region of Argentina, but also spilled over into the capital city. In 1905, the Radical Civic Union led another revolt in Buenos Aires, which was unsuccessful. In addition, the anarchist- and socialist-influenced labor movement brought about by European immigrants contributed to the political turmoil with massive strikes such as the "tenants' strike" of 1907 and the "Red Week" of 1909.

The coup of 1930, which would oust President Yrigoyen, is often seen as a turning point in Argentine politics, where democracy was replaced with military rule. However, we have seen that this coup was hardly without precedent. Four times between 1880 and 1905, revolts started or reaching Buenos Aires shook the country and often achieved a fair amount of success. This suggests a degree of instability in Buenos Aires that was much more extreme than in Chicago.

Chicago did have uprisings, most notably the Haymarket Riot of 1886 and the Chicago Race Riot of 1919. The labor union movement also made its presence felt, of course, as illustrated by the Haymarket episode, the "Teamsters' strike" of 1905 and the "Garment strike" of 1910, all of which ended with many killed and injured in confrontations with police. Broadly speaking, Chicago was hardly a model of 
social order. Although, in 1890, homicide rates were about two times higher in Buenos Aires than in Chicago, by the 1920s, after Prohibition, the picture is essentially reversed.

While both Chicago and Buenos Aires had uprisings, their consequences were vastly disparate. If the immediate consequences of the Haymarket riot were the controversial execution of seven anarchists and a boost to May Day commemorations around the world, the Buenos Aires events had far more direct consequences for the Argentinean political system. The Revolution of the Park, in 1890, while defeated by government forces, still led to the fall of President Celman. The 1893 Revolution also took over the Casa Rosada before being defeated. In fact, the consensus interpretation of the Sáenz Peña law among historians describes it as largely motivated by the rising tension and the pressure exerted by the Radical opposition, galvanized by the battle cry of the secret ballot and universal suffrage, and by the labor movement. As a result of the electoral reform, the Conservative Republic also met its demise in 1916, when the Radical Yrigoyen won the presidency in the first election under the new rules.

What can explain these different consequences? The relative immaturity of the Argentine democracy certainly played a part, but it is also the case that the location of Buenos Aires at the very heart of the country's politics, as the all-important capital city in which by 1914 more than one in six Argentineans lived, made Porteño turmoil more consequential. In fact, Argentina still is one of the countries with the highest concentration of population around the capital city in the whole world-it has the highest concentration among countries with large territories-using the measure developed in Campante and Do (2010).

The centrality of Buenos Aires, of course, is not simply related to its designation as the capital city. From the very early years of the independent Republic, the city's enormous weight in terms of population and economic activity, which was engendered by its position as the gateway to the hinterland and by the low labor intensity of the dominant cattle-raising activity, posed a constant challenge to the Argentinean federal system. This is illustrated by the perennial tension between the Province of Buenos Aires - which was still fighting the idea of joining the Union, in the battlefield, as late as 1862 - and the other provinces, which culminated in the federalization of the city of Buenos Aires in 1880. Chicago, in contrast, was a relative latecomer to the Union, which the state of Illinois joined more than 40 years after independence - and Chicago, of course, is not even the capital of that state.

In any event, the fact is that the 1890 Revolution, for instance, started in the Artillery Park, located a half-mile from the Casa Rosada. The Haymarket riot, in contrast, took place some 700 miles away from the White House. For this reason, it is very likely that the political and social instability that brewed in the similar environments of Chicago and Buenos Aires, both of which were undergoing rapid transformation, had much more detrimental consequences for Argentina in terms of the consolidation of its democracy.

There is a strong connection between urban concentration in and around a primate capital and political instability (Ades and Glaeser 1995; Campante et al. 2016), which reflects causality running in both directions. For at least 2500 years, urban mobs have had the ability to force political change. In 509 B.C., Lucius Junius 
Brutus led the coup that ousted the last Roman King. In 411, Athenian democracy was ended by another urban coup. The history of Europe's great medieval cities, like Bruges, is replete with organized opposition to aristocratic rules. France's political instability in the nineteenth century owes much to the power of Parisian mobs to topple governments.

The fundamental ingredient in a successful revolt is scale: isolated activists can do little to challenge a government. Urban density makes it easier to form connections, which can create a sufficiently large uprising. Riots are, after all, a primarily urban phenomenon (DiPasquale and Glaeser 1997). The political importance, however, of urban riots depends on their proximity to power (Campante et al. 2016). That explains why uprisings in Buenos Aires were so much more important than those in Chicago.

The political power of urban mobs can lead to two political responses. The first is to placate the mob with public handouts and services (Campante et al. 2016). Classical Rome's vast bread doles, for example, can be understood as an attempt to cool the mobs organized by the Gracchus and others. The general tendency of developing countries to target public services to the capital is a more modern example of this phenomenon. Of course, placating urban unrest has the effect of then further expanding the size of the capital city. For this reason, the connection between political instability and capital size is two-sided. A large capital appears to create instability, and instability means that services flow to the capital, which attracts migrants and further increases its size.

In some cases, political leaders respond to the threat created by urban unrest by moving their capital far away from the city (Campante et al. 2016). When Peter the Great moved his capital to St. Petersburg he was protecting his regime from the influence of Muscovites. Likewise, America's founders chose to create a new capital on the Potomac, in part to reduce the influence of people in New York and Philadelphia (America's first capitals). America's largest riot, the 1863 New York City draft riot, could have had a much larger influence on history if New York, rather than Washington, had been the capital of the U.S.

In light of these facts, we are led to conclude that the large, primate capital of Argentina might have played a major role in the nation's twentieth century political problems.

\section{Did those differences matter?}

We have argued that, despite the enormous similarities between Chicago and Buenos Aires, there were substantial differences in income, education, industrial development and political institutions. The main question that remains is the extent to which each one of those differences might be able to account for the different paths of Buenos Aires and Chicago, and more broadly those of Argentina and the U.S., in the twentieth century. In principle, any one of those differences could have played a role. A "big push" theory of growth (e.g. Rosenstein-Rodan 1943; Murphy et al. 1989) might suggest that higher levels of income could have put the U.S. on a path towards industrialization. Human capital might have influenced growth 
directly, or indirectly, through industrial development or political change. The fact that Buenos Aires was far less industrial than Chicago, and far more dependent on natural resources, set the stage for the declines of the 1930s, when the price of natural resources plummeted. The political differences of Buenos Aires might have played a role in explaining the political traumas that Argentina experienced over the twentieth century.

A system with two countries and four potential explanatory variables is, of course, overdetermined. The only way to evaluate the relative importance of these four factors is to bring in other countries. We will do this directly, by running a set of cross-national regressions, while drawing on the long literature on the determinants of differences in country-level prosperity, such as Hall and Jones (1999). Although the limitations of cross-country regressions are well known, they can nevertheless provide us with a benchmark quantitative assessment of our candidate explanations.

We start from the premise that there is a link between relevant outcomes such as income today and variables in the early twentieth century, and that we can look at 100-year regressions at the cross-country level to estimate the impact that the latter have on the former. We then multiply these estimated coefficients by the differences in initial conditions between the U.S. and Argentina, to get a sense of the amount of today's differences that can be explained by the different initial conditions in this specific comparison. Essentially, we are assuming a model of the following form:

$$
Y_{\text {Today }, j}=\sum_{i} \beta_{i} X_{i, 1900, j}+\varepsilon_{j}
$$

where $Y_{\text {Today } j}$ is country $\mathrm{j}$ 's outcome today, $\beta_{i}$ is the coefficient on explanatory variable $i, X_{i, 1900, j}$ is the value of explanatory variable $i$ in country $j$ in 1900 and $\varepsilon_{j}$ is a country-specific error term. This estimating equation then suggests that the differences in outcomes between Argentina and the U.S. today can be understood as follows:

$$
Y_{\text {Today }, \mathrm{US}}-Y_{\text {Today,Argentina }}=\sum_{i} \beta_{i}\left(X_{i, 1900, \mathrm{US}}-X_{i, 1900, \text { Argentina }}\right)+\varepsilon_{\mathrm{US}}-\varepsilon_{\text {Argentina }} .
$$

The ratio $\frac{\beta_{i}\left(X_{i, 1900, \mathrm{US}}-X_{i, 1900, \mathrm{Argentina}}\right)}{Y_{\text {Today,US }}-Y_{\text {Today,Argentina }}}$ is the share of the current differences between Argentina and the U.S. that can be explained by variable $i$. The cross-country regressions will furnish our estimates of the coefficients $\beta_{i}$.

Our primary outcome variable is the logarithm of per capita GDP in 2000, calculated using purchasing power parity and taken from the Maddison (2008) data set. Since GDP is typically measured at the country, not city level, we will be using national GDP measures and national characteristics a century ago. Using this variable, the difference in log of GDP per capita between the U.S. and Argentina is 1.2, which means that American incomes were $230 \%$ higher than those in Argentina in 2000. This is, of course, much larger than the 48\% difference shown in 1900 GDP data [also from the Maddison (2008) data set]. 
We will also look at a political outcome variable, as well as GDP, because so much of the work on Argentina has emphasized the interaction of political and economic distress (e.g. della Paolera and Gallo 2003). We focus on the democracy score of the country, as measured by the "Polity 2 " variable from the Polity IV data set, averaged between 1970 and 2000. This measure subtracts a 0-to-10 "Autocracy" score from a 0-to-10 "Democracy" score (both of which constitute indices of institutional features), resulting in values ranging from -10 to 10 . We use a longrun political average, because democracy measures vary substantially from year to year. Moreover, Argentina's current political environment is far more stable than even its recent past, and looking only at the most recent data would understate the extent of the country's political turbulence. (For the period average, Argentina scores 2.06, while the U.S. scores 10.) We will look at GDP first, then politics, and then ask whether controlling for current politics helps us to understand the differences in GDP.

Our key explanatory variables are per capita GDP in 1900 [from Maddison (2008)], which is available for 37 countries, and measures of school enrollment for the same year (from Banks). Our school variable adds together the enrollment rates for primary, secondary and university education. (The most important variable is primary education, and results are similar if we use that variable alone.) We have 36 countries with this variable. Our third variable is the share of manufacturing in total output in the early twentieth century, which we obtain from multiple sources (Milward and Saul 1977; Bulmer-Thomas 1994; Engerman and Sokoloff 2000; Urquhart 1993). (The actual year varies by country, between 1899 and 1920; most come from around 1913.) This variable captures the degree of industrialization a century ago, but it is only available for 16 countries. Finally, we use the average of the Polity 2 variable between 1870 and 1900 to measure institutional development.

As these variables are often quite collinear, and as they are available for different subsamples of countries, we begin by examining the univariate relationship between these explanatory variables and the logarithm of per capita GDP in 2000. Regression (1) in Table 3 shows the relationship between GDP in 1900 and GDP today. The lagged variable explains $65 \%$ of the variation in current GDP across the 37 countries. Essentially, the elasticity is one, meaning that if a country was $10 \%$ richer than another in 1900 , then it is $10 \%$ richer today.

Figure 5 shows the relationship between income in 1900 and income today. The relationship certainly is tight, but Argentina is an outlier, falling substantially below the regression line. If we were to accept the coefficient of 1.01 on log GDP per capita in 1900, then initial income levels would only predict a 0.4 log point difference today. This translates into a difference of about $49 \%$, which is just about one-fifth of the total difference in incomes between Argentina and the U.S.

In the second regression, we look at the connection between our schooling variable and GDP today. The R-squared rises to $70 \%$, and as the share of the population attending school increases by 5\%, then GDP today increases by $0.7 \log$ points. This is about doubling. This captures the enormously strong connection that schooling in the past appears to have with current income levels (as in Glaeser et al. 2004). Figure 6 shows the connection between schooling enrollments in 1900 and 


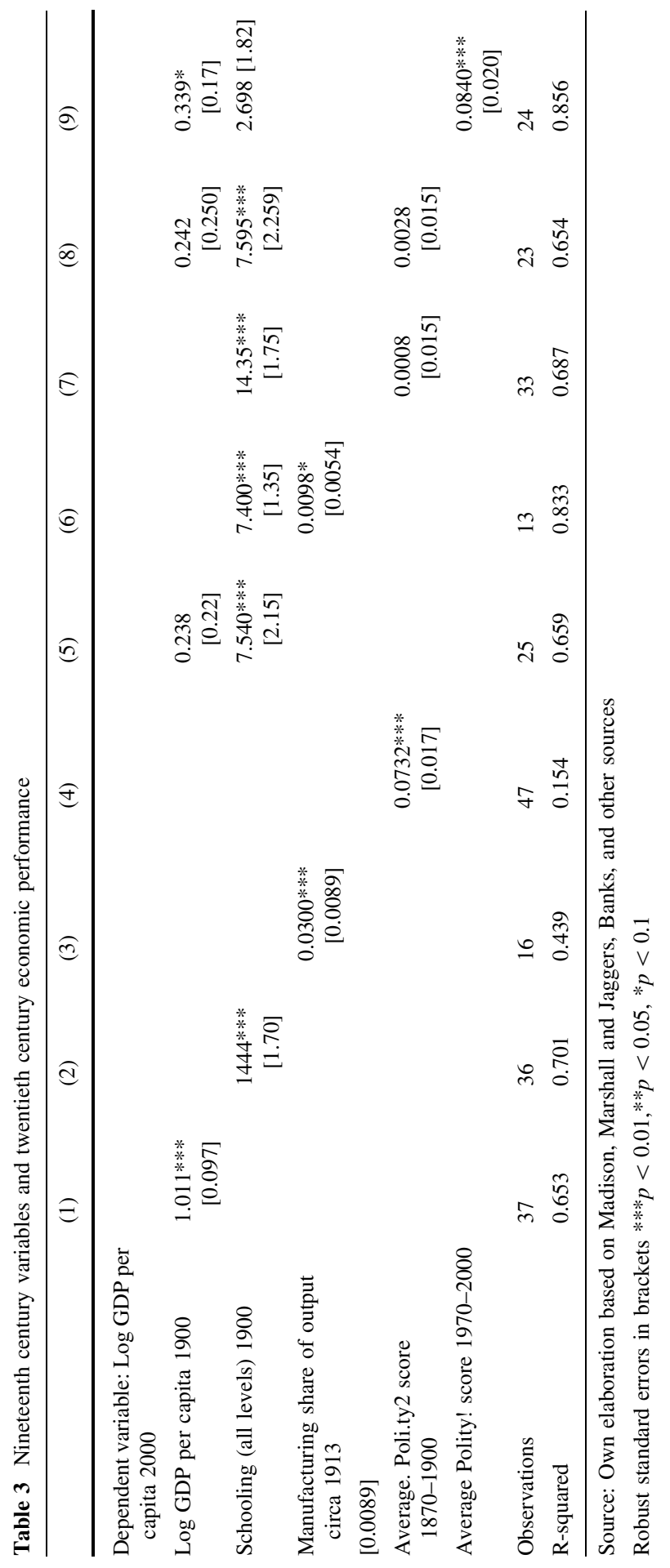




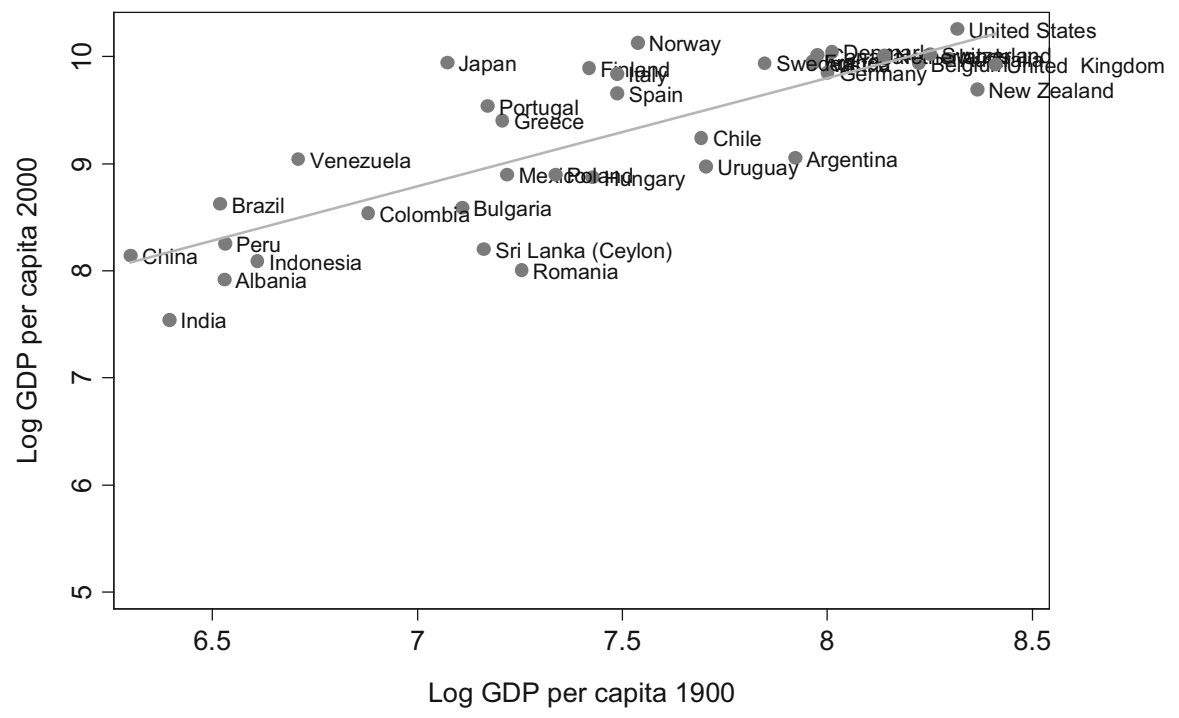

Fig. 5 GDP per capita in 1900 and in 2000. Source: GDP per capita from Maddison

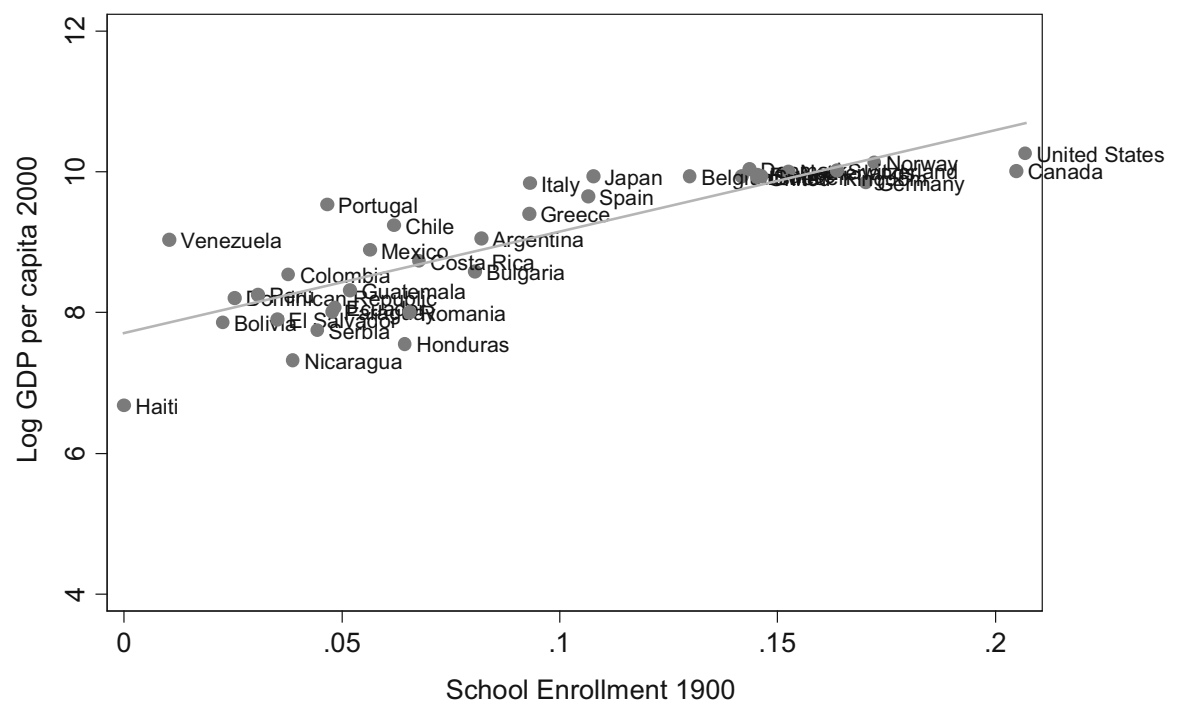

Fig. 6 School Enrollment in 1900 and GDP per capita in 2000. Source: GDP per capita from Maddison

income today. In this case, Argentina lies on the regression line and the U.S. is somewhat beneath it.

Can the difference in schooling explain current income levels? We will return to this question later, when we have controlled for other variables, but a simple thought experiment using the univariate coefficient suggests that power of education. The gap in enrollment rates between Argentina and the U.S. in 1900 is 0.12. While 
Buenos Aires may have had comparable enrollment rates to Chicago, outside the city education levels were far lower than in the U.S. Multiplying 0.12 by the estimated coefficient of 14.4 suggests a current income difference of 1.80 log points, which is actually substantially larger than the realized income difference. While this fact tells us nothing about whether schooling is actually determining the gap or whether it is just proxying for something else, the raw coefficient suggests that the cross-country relationship in income suggested by 1900 schooling levels can account for the current differences between Argentina and the U.S.

Our third regression looks at the share of manufacturing in output around 1913. We only have 16 observations, but again, the relationship with current income is positive and significant. As in the case of income, however, even the univariate regression does not suggest that this variable is powerful enough to explain more than a quarter of the current difference between the U.S. and Argentina.

Finally, we look at the correlation between political instability in the late nineteenth century and GDP today. The explanatory power of this variable is much weaker than the other variables. As Fig. 7 shows, there are plenty of once unstable countries that are now quite prosperous. Argentina may have been less stable than the U.S., but it was more stable and democratic than many European countries which are now far more prosperous. Still, the correlation between nineteenth century instability and wealth today might explain something of the current differences between Argentine and U.S. wealth. Using the univariate coefficient, we find that the differences in the historical politics measures would predict a $0.7 \log$ point difference in incomes today, which is more than half of the total income differences.

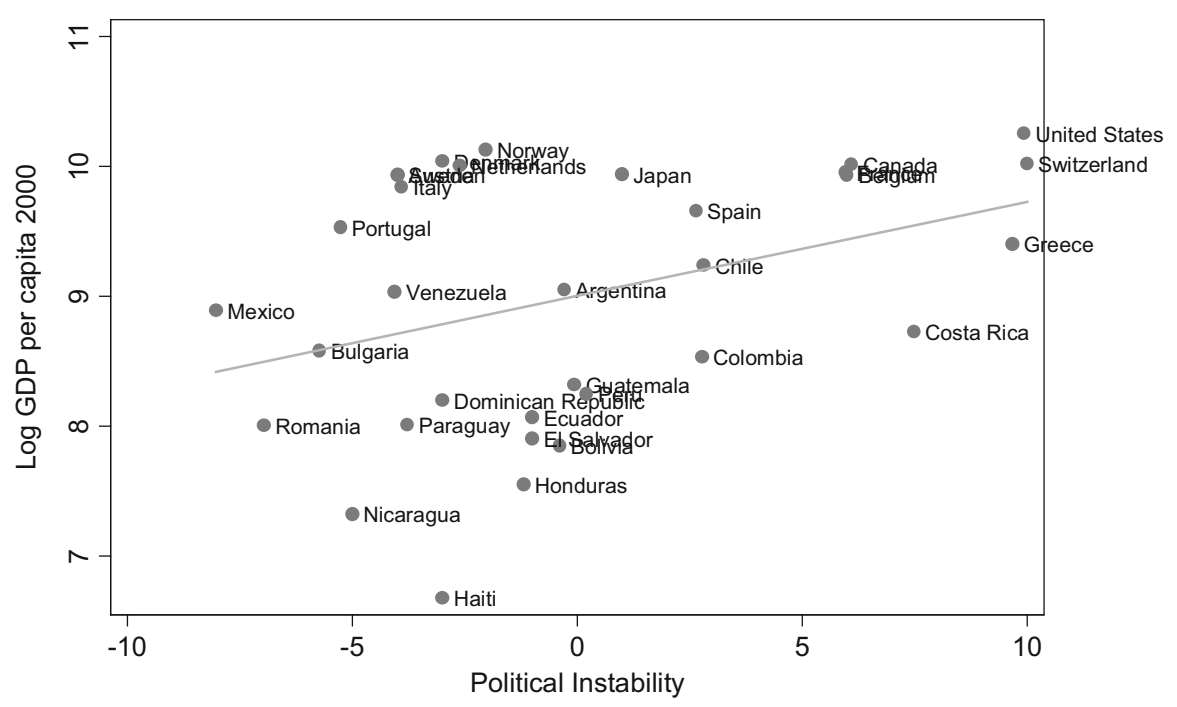

Fig. 7 Political Instability and GDP per capita in 2000. Source: GDP per capita from Maddison. Political instability from Marshall and Jaggers 
In sum, the univariate relationships suggest that human capital and politics both have a chance at explaining significant amounts of the differences in income between the U.S. and Argentina. The other variables appear less important. To sort out the relative importance of these different variables, we now turn to multivariate regressions. In regression (5), we include both GDP and schooling as control variables. The coefficient on GDP drops by almost $75 \%$ and becomes statistically indistinguishable from zero; the coefficient on schooling retains statistical significance but drops by one-half. The bulk of this drop does not come from controlling for income, but rather from restricting the sample size. We do not have GDP figures in 1900 for many poorer countries, especially in Latin America; as a result, the sample becomes wealthier and the coefficient (which is smaller across richer countries) becomes smaller.

In regression (6), we control for manufacturing and schooling. When we control for schooling, the coefficient on manufacturing is very small, and just borderline significant at the $10 \%$ level. The coefficient on the schooling variable is 7.4 . When we include GDP in the regression (not shown), controlling for manufacturing drives the coefficient on GDP in 1900 essentially to zero; the coefficients on the other two variables remain largely unaffected, but the significance of manufacturing is removed. In regression (7), we control for politics as well as the schooling variable. In this case, politics becomes insignificant, and the coefficient on schooling is essentially the same as in the univariate case.

These results strengthen the case for the central role played by differences in schooling, but we still need to investigate what happens when the full set of variables is simultaneously included. This is what we do in regression (8) (with the exception of manufacturing, which causes our sample to shrink too much). With all three variables, schooling remains significant with a coefficient of 7.6. The other two variables are not. We take away from these regressions the view that no variable, other than schooling in 1900, has a reliable correlation with GDP in 2000. The coefficient on schooling ranges from 7.5 to 14.5 .

We have already shown that if the schooling coefficient is 14.5 it can more than explain the current differences between Argentina and the U.S. How much of those differences can schooling in 1900 predict if the coefficient is smaller? For example, if the coefficient is 10 , then the differences in schooling levels in 1900 would predict a $1.2 \mathrm{log}$ point difference in current incomes, which is exactly the difference in 2000. If the coefficient is 7.5 , then the schooling difference can explain $75 \%$ of the current income differences. As such, human capital in 1900 seems to predict the lion's share of the difference in current incomes.

But why would historical human capital levels predict such large income differences? One obvious explanation is that human capital in 1900 predicts human capital today and that current human capital differences explain the gap between the U.S. and Argentina. It is certainly true that schooling in 1900 is strongly correlated with schooling today: the correlation coefficient between our enrollment data and total years of schooling in 2000 taken from Barro-Lee (2000) is $85 \%$.

Moreover, years of schooling today certainly strongly predict income levels. A univariate regression of $\log$ of GDP on total years of schooling in 2000 finds a coefficient of 0.369 (R-squared: 0.745 ). The gap in total years of schooling between 
Argentina and the U.S. today is 3.22 years (12.05-8.83). Taking the estimated univariate coefficient literally suggests that current schooling differences can explain $98 \%$ of the current GDP gap between the U.S. and Argentina.

But what does this univariate coefficient mean? Our cross-country coefficient certainly implies a much higher effect than estimates from individual-level studies, where an extra year of schooling rarely increases wages by more than 10 or at most $15 \%$ (e.g. Ashenfelter and Krueger 1994; Card 1999). If that lower range of coefficients represented the link between education and productivity, then higher education levels in the U.S. can explain less than one-third of the difference in incomes between Argentina and the U.S.

How can we reconcile the gap between individual-level estimates of human capital effects and country-level estimates of human capital effects? One view is that the larger coefficients at the national level represent human capital spillovers. Living in a country with more skilled individuals may make everyone more productive, perhaps because skilled workers are responsible for determining the level of technology in a given country. However, cross-metropolitan area studies of human capital spillovers generate an estimate that is positive, but far too small to account for the size of the cross-country coefficient (Rauch 1993; Acemoglu and Angrist 2000).

One explanation for the difference between the cross-city estimates and the crosscountry estimates is that - as suggested by Glaeser et al. 2007), building on the famous Lipset (1959) hypothesis-schooling is responsible for political outcomes. In particular, stable democratic institutions tend to be predicated on the level of schooling of the citizenry. According to this view, Argentina's problematic political history during the twentieth century has its roots in the relatively lower human capital levels of the country in $1900 .^{2}$ To test this hypothesis, in Table 4, we reproduce the exercise from Table 3, but now with political stability between 1970 and 2000 as our dependent variable.

The first four regressions repeat the univariate relationships shown in Table 3. As before, all of these variables predict the outcome variable. Schooling has the strongest correlation with democracy during the late twentieth century, but the other variables also predict democratic stability. In the fifth regression, we include all of the variables-again with the exception of manufacturing, which depletes too much of the sample. In this case, schooling continues to predict democracy, and the coefficient is essentially unchanged. None of the other variables remain statistically significant.

Can the schooling differences between Argentina and the U.S. explain the instability of late twentieth century Argentina, in a quantitative sense? The difference in the two outcome variables is 7.94. The estimated coefficient on schooling is approximately 52. Multiplying 52 by the schooling difference in 1900

\footnotetext{
2 The relatively low levels of human and physical capital might have influenced political instability in Argentina through yet another channel. Campante and Chor (2012) show evidence that, in countries that are relatively land-abundant, individual schooling tends to be more strongly associated with political activity, particularly for "conflictual" modes of activity such as demonstrations. This suggests that, for the case of Argentina, its dearth of physical and human capital relative to the U.S. meant that the country's investments in expanding education were partly translated into relatively more political conflict.
} 
Table 4 Nineteenth century variables and twentieth century democratic institutions

\begin{tabular}{|c|c|c|c|c|c|}
\hline & (1) & (2) & (3) & (4) & (5) \\
\hline \multicolumn{6}{|c|}{ Dependent variable: average Polity2 score 1970-2000 } \\
\hline Log GDP per capita 1900 & $\begin{array}{c}5.365^{* * *} * \\
{[1.26]}\end{array}$ & & & & $\begin{aligned} &- 1.17 \\
& {[2.17] }\end{aligned}$ \\
\hline Schooling (All levels) 1900 & & $\begin{array}{c}57.10^{* * * *} \\
{[9.81]}\end{array}$ & & & $\begin{array}{l}51.98^{* *} \\
{[21.63]}\end{array}$ \\
\hline $\begin{array}{l}\text { Manufacturing share of output } \\
\text { circa } 1913\end{array}$ & & & $\begin{array}{l}0.169 * * \\
{[0.070]}\end{array}$ & & \\
\hline $\begin{array}{l}\text { Average Polity2 score } \\
1870-1900\end{array}$ & & & & $\begin{array}{c}0.514 * * * \\
{[0.12]}\end{array}$ & $\begin{array}{l}0.12 \\
\quad[0.144]\end{array}$ \\
\hline Observations & 36 & 34 & 15 & 48 & 23 \\
\hline R-squared & 0.358 & 0.465 & 0.251 & 0.219 & 0.38 \\
\hline
\end{tabular}

Source: Own elaboration based on Madison, Marshall and Jaggers, Banks, and other sources

Robust standard errors in brackets $* * * p<0.01, * * p<0.05, * p<0.1$

yields an estimate of 6.24 , which is $79 \%$ of the observed instability difference. While the schooling differences cannot explain all of the differences in democracy, they can certainly go most of the way.

Our final exercise is to see whether the connection between education and democracy can explain why schooling in 1900 is so correlated with incomes today. Going back to the specification from Table 3, we now include the twentieth century politics variable in a regression that also includes schooling in 1900. Including this variable causes the coefficient on schooling to decrease by more than a third, relative to the univariate regression, but the coefficient remains 8.87 , which is still quite high. If we include both democracy today and GDP in 1900 as controls, then the coefficient on schooling in 1900 falls to 2.7 and is no longer significantly different from zero, as shown in regression (9). We interpret these regressions as suggesting that much of the impact of relatively low levels of schooling in Argentina went through political channels.

Whatever remains of the schooling effect may work either through unmeasured political channels, or direct human capital effects, or through better technology. Hopefully, further work will better help us to understand the strong connection between historical schooling and current GDP in a broader context. In our specific case, however, it does seem to be true that Argentina's collapse, relative to the U.S., had much to do with lower education levels.

\section{Conclusion}

There were many similarities between the historical trajectories of Chicago and Buenos Aires. Both cities were conduits for natural wealth coming from the American hinterland to the markets of the east. Both cities dealt in the same products, first animals and then grain. Both cities grew spectacularly and were among the wealthiest places on earth a century ago. 
However, even 100 years ago there were substantial differences between the two cities. Chicago was wealthier and better educated. Its industries were more advanced and more capital intensive. Its political system was more stable, and its instability was less consequential. All told, Buenos Aires looks more like a place that became rich because of a boom in natural resources. Chicago used those natural resources and then transitioned into becoming a more modern industrial place, with substantially greater levels of physical and human capital.

The gap in industrial development and human capital then set the stage for the twentieth century. Across countries, schooling in 1900 strongly predicts success today, partially because less schooled places have had far worse political outcomes. America's greater level of human capital in 1900 surely deserves much credit for its track record of twentieth century political stability. In this regard, the effects of the lower levels of human capital in Buenos Aires were in turn magnified by its overwhelming political importance within Argentina. All in all, the divergence between Chicago and Buenos Aires reflects the fact that Buenos Aires in 1900 had wealth levels that were far higher than its actual level of human and physical capital accumulation.

From a slightly broader perspective, particularly within the context of Latin America, this conclusion sounds somewhat dispiriting. After all, by the standards of the region, Argentina did invest early and heavily in human capital accumulation and achieved a stage of near-universal literacy and enrollment way before most of its neighbors-many of which are still considerably off that mark. Still, it seems that the human capital lag it displayed in comparison with the US or Western Europe, even in its heyday, ended up trapping the country with relatively immature political institutions. This fragility was in turn made more acute by the geographical concentration of population and economic activity around Buenos Aires and eventually plunged the country into a cycle of instability from which its economic performance could not escape unscathed. President Sarmiento seemed to have his finger on the right issue when he stated that "all problems are problems of education", but for Argentina we might add that this recognition was not enough.

Open Access This article is distributed under the terms of the Creative Commons Attribution 4.0 International License (http://creativecommons.org/licenses/by/4.0/), which permits unrestricted use, distribution, and reproduction in any medium, provided you give appropriate credit to the original author(s) and the source, provide a link to the Creative Commons license, and indicate if changes were made.

\section{References}

Acemoglu D, Angrist J (2000) How large are human-capital externalities? Evidence from compulsory schooling laws. NBER Macroecon Annu 15:9-59

Ades AF, Glaeser EL (1995) Trade and circuses: explaining urban giants. Q J Econ 110:195-258

Alonso Paula (1993) Politics and elections in Buenos Aires, 1890-1898: the performance of the radical party. J Latin Am Stud 25(3):465-487

Anuario Estadístico de la Ciudad de Buenos Aires, Año VI -1896-, G. Kraft, Buenos Aires, 1897

Anuario Estadístico de la Ciudad de Buenos Aires (Resúmen de los años 1915/23), Briozzo Hnos., Buenos Aires, 1925

Anuario Municipal 1937-1938, sin datos de imprenta (colección de la biblioteca del Ministerio de Economía y Producción) 
Ashenfelter O, Krueger Alan (1994) Estimates of the economic return to schooling from a new sample of twins. Am Econ Rev 84(5):1157-1173

Banerjee AV, Bénabou R, Mookherjee D (eds) (2006) Understanding poverty. Oxford University Press, Oxford

Barro RJ, Jong-Wha L (2000) International data on educational attainment: updates and implications. CID working paper no. 042

Brock HG (1919) Boots and shoes, leather, and supplies in Argentina, Uruguay, and Paraguay. United States Dept. of Commerce, Government Printing Office, Washington

Brown JC (1976) Dynamics and autonomy of a traditional marketing system: Buenos Aires, 1810-1860. Hispanic Am 56(4):605-629

Bulmer-Thomas Victor (1994) The economic history of Latin America since independence. Cambridge University Press, Cambridge

Campante FR, Chor D (2012) Schooling, political participation, and the economy. Rev Econ Stat 94(4):841-859

Campante FR, Quoc-Anh D (2010) A centered index of spatial concentration: expected influence approach with an application to population and capital cities. HKS Faculty Working Papers RWP09005

Campante F, Quoc-Anh D, Beranrdo G (2016) Capital cities, conflict, and misgovernance. Harvard Kennedy School (unpublished)

Card DE (1999) The causal effect of education on earnings. Handb Labor Econ III I:1801-1863

Censo Escolar de la Nación. various years. Argentina

Censo General de la Ciudad de Buenos Aires. various years. Argentina

Censo Nacional. various years. Argentina

Della Paolera G, Gallo E (2003) Epilogue: the Argentine Puzzle. In: della Paolera G, Taylor A (eds) A new economic history of Argentina. Cambridge University Press, Cambridge

Di Tella G, Manuel Z (1967) Las Etapas del Desarrollo Económico Argentino. Editorial Universitaria de Buenos Aires, Buenos Aires

DiPasquale D, Glaeser EL (1997) Incentives and social capital: are homeowners better citizens?" Harvard Institute of economic research working papers 1815. Harvard-Institute of Economic Research

Engerman SL, Sokoloff KL (2000) History lessons: institutions, factor endowments, and paths of development in the new world. J Econ Perspect 14(3):217-232

Engerman SL, Haber S, Sokoloff KL (2000) Inequality, institutions, and differential paths of growth among new world economies. In: Menard C (ed) Institutions, contracts and organizations. Edward Elgar, Cheltenham

Glaeser EL, La Porta R, Lopez-de-Silanes F, Shleifer A (2004) Do institutions cause growth? J Econ Growth 9:271-303

Glaeser EL, Ponzetto G, Shleifer Andrei (2007) Why does democracy need education? J Econ Growth 12(2):77-99

Hall Robert E, Jones Charles I (1999) Why do some countries produce so much more output per worker than others? Q J Econ 114(1):83-116

Hanson SG (1938) Argentine meat and the British market: chapters in the history of the Argentine meat industry. Stanford University Press, California; H. Milford, Oxford University Press, London

Lipset SM (1959) Some social requisites of democracy: economic development and political legitimacy. Am Polit Sci Rev 53(1):69-105

Maddison A (2008) Historical statistics for the world economy: 1-2006 AD. Last updated october 2008. http://www.ggdc.net/maddison/

Milward Alan S, Saul SB (1977) Development of the economies of Continental Europe, 1850-1914. Harvard University Press, Cambridge

Murphy KM, Shleifer A, Vishny RW (1989) Industrialization and the big push. J Polit Econ 1003-1026

Población de Buenos Aires. Various Years. Buenos Aires

Rauch James E (1993) Does history matter only when it matters little? The case of city-industry location. J Urban Econ 108(3):843-867

Rock D (1987) Argentina, 1516-1987: from Spanish Colonization to Alfonsín. University of California Press, California

Rosenstein-Rodan PN (1943) Problems of Industrialization of Eastern and South-Eastern Europe. Econ J 53(210/211):202-211

Sampay A Enrique (1974) Constitución y pueblo, 2nd edn. Cuenca Ediciones, Buenos Aires

United States Census. Various years. Washington DC 
Urquhart MC (1993) Gross national product, Canada, 1870-1926: the derivation of the estimates. McGillQueen's University Press, Buffalo

Williamson Jeffrey G (1995a) Reform, recovery, and growth: Latin America and the Middle East. University of Chicago Press, Chicago

Williamson Jeffrey G (1995b) The evolution of global labor markets since 1830: background evidence and hypotheses. Explor Econ Hist 32(2):141-196 